\title{
PARTICIPATORY MAPPING IN COMMUNITY PARTICIPATION - CASE STUDY OF JESENÍK, CZECH REPUBLIC
}

\author{
JIŘí PÁNEK \\ Department of Development and Environmental Studies, Palacký University Olomouc, Czech Republic \\ Manuscript received: December 3, 2017 \\ Revised version: August 3, 2018
}

\begin{abstract}
PÁNeK J., 2018. Participatory mapping in community participation - case study of Jeseník, Czech Republic. Quaestiones Geographicae 37(3), Bogucki Wydawnictwo Naukowe, Poznań, pp. 151-162. 10 figs, 1 table.

ABSTRACT: Community participation has entered the $21^{\text {st }}$ century and the era of e-participation, e-government and e-planning. With the opportunity to use Public Participation Support Systems, Computer-Aided Web Interviews and crowdsourcing mapping platforms, citizens are equipped with the tools to have their voices heard. This paper presents a case study of the deployment of such an online mapping platform in Jeseník, Czech Republic. In total, 533 respondents took part in the online mapping survey, which included six spatial questions. Respondents marked 4,714 points and added 1,538 comments to these points. The main aim of the research was to find whether there were any significant differences in the answers from selected groups (age, gender, home location) of respondents. The results show largest differences in answers of various (below 20 and above 20 year) age groups. Nevertheless further statistical examination would be needed to confirm the visual comparison.
\end{abstract}

KEY WORDS: emotional maps, crowdsourcing, geoparticipation, online maps, community participation

Corresponding author: Jiři Pánek, jirkapanek@gmail.com

\section{Introduction}

Public participation in urban planning has become a well-used practice in the past decade(s). Innovative methods of involving citizens in decision-making processes and the planning of public spaces are entering the thoughts of city planners and the terminology can be found in the vocabulary of municipal representatives. GeoParticipation, as a concept which involves citizens in the community planning and decision-making process (Pánek 2016) via digital mapping methods, has been strengthened by the rise of Public Participation GIS (Dunn 2007) as well as the emergent field of neocartography (Rød et al. 2001, Cartwright 2012). Various Public Participation Support Systems, Computer-Aided Web Interviews and crowdsourcing mapping platforms have emerged in the last ten years.
This paper represents another piece of the puzzle, through a vast amount of testimonies concerning good and bad practices in participatory mapping. The author presents his own online mapping platform, as deployed in collaboration with the local municipality of Jeseník, Czech Republic. There were two aims in this case study: 1) as is typical of participatory action researchers, the first aim was to draw tangible outcomes from the research in order to improve local participation and help the municipality to involve the residents in the process of participatory planning; 2) to find which groups (age, gender, neighbourhood) will have the highest spatial variance in their perceptions of spaces. The paper presents the results from a case study that involved 533 respondents from Jeseník who answered six spatial questions about their perceptions of the city. The results were later used 
by the city in short-term actions and in long-term strategic planning.

The paper first presents the study area and historical changes in the population structure of the inhabitants of Jeseník. After description of the methodology and data collected, the author focused on results by describing each question results accompanied by maps and comments from respondents. The results are followed by section about how the city used or is planning to use the results. The final chapter reflects the conclusion and visions for further development of the platform used for data collection.

\section{Study area}

The case study was implemented in Jeseník, a town in the Olomouc region of the Czech Republic, with a total population of 11396 and with a history reaching back to the $12^{\text {th }}$ century. Historically, Jeseník was the largest Czech city in the Duchy of Nysa, in the area that is currently the Czech Republic and Poland. Prior to the establishment of Czechoslovakia, Jeseník was a German speaking city. According to the Austrian administration census of 1910 , the town had 6,859 inhabitants with 6,619 permanent residents. Based on language distribution, 99.5\% (6,552) spoke German, $0.24 \%$ (16) Czech and 0.19\% (13) Polish. Jews were not allowed to declare themselves to be Yiddish so most declared themselves to be German (Patryn 1912). In the 1930s the Czech and Polish inhabitants were forced out of the city by the strong Sudetenland party and Germans moved in. The population rose to 10,584 .

In contrast, in 1945 the German population was expelled in accordance with the Benes Decrees and in 1947 the city was no longer known as Frývaldov (Freiwaldau in German), and was renamed Jeseník. The population dropped to 7,129 . Over the following forty years of the communist regime the city lost most of its historical built-up areas. In 1960 the city's importance as an economic centre for the region diminished when it lost its title of county (LAU1) city. Since 1991 the population of the city has been decreasing and the average age has been increasing; the latter is currently 44.1 (compared to the national average of 42.0) (Czech Statistical Office 2017).
In last national census organised in 2011 (Czech Statistical Office 2013), the language distribution in Jeseník was following Czech (89.4\%), Slovak $(1.7 \%)$, German $(0.5 \%)$, Polish $(0.1 \%)$. The latest information (from 2017) estimates the population of Jeseník at 11,396. The rapid changes in the population structure of Jeseník have created a particular atmosphere in the city and among its citizens. The local administration decided to use participatory mapping in order to encourage the residents to participate in community planning and the development of public spaces.

\section{Methods and data}

The case study was initiated by a representative of the local municipality and the author took part in the process as an action researcher (Brydon-Miller et al. 2003). The aim was to achieve practical benefits and generate practical information from the research, which could be used by the community involved in the case study. The data collection was organised by the municipality during May and June 2017 using a combination of analogue paper-based maps (see Fig. 1a), used during the neighbourhood festival in the main square of Jeseník ( $\mathrm{n}=156$ respondents), and a web-based digital map (see Fig. 1b) designed by the author as a simple crowdsourcing webpage ( $\mathrm{n}=377$ respondents). Both data collection channels were administered by the city representatives. The neighbourhood festival as well as the crowdsourcing webpage were advertised at the city webpage, city Facebook profile as well as in local newspaper. Furthermore direct email to local high schools was sent in order to attract also teenagers from Jeseník to fill in the survey. The language of the survey was Czech. For the data collection, points were identified as the optimal feature class and beside sketching polygons (Jankowski et al. 2016), their use was the predominant method for spatially-explicit preference mapping. Brown and Pullar (2012) suggested that points instead of polygons be used in future PPGIS applications as points can be pro precise, although it is needed to have higher amount of answers. On the other hand polygon areas outside of hotspots may represent potential spatial error from using polygons (p. 239). It would be possible to use fuzzy multi-points similar to 

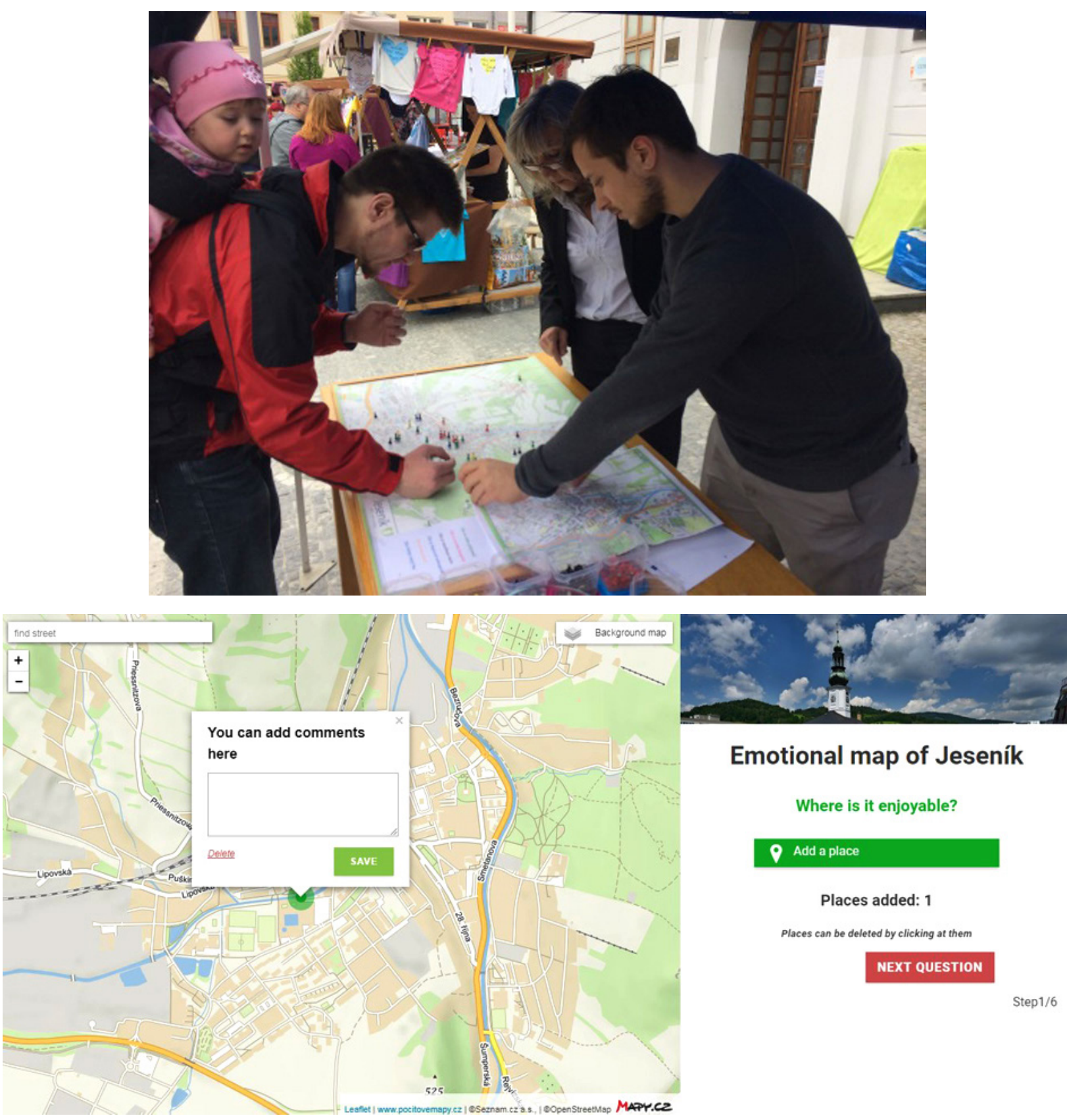

Fig. 1. Analogue mapping during the festival (up) and printscreen of the web-mapping platform (down).

the application Spraycan (Huck et al. 2014), but in the analogue version it would be technically very complicated to describe fuzzy-multi points with pins. Although some agencies are using paper stickers (even transparent ones), the author declined this possibility as the issue of overlapping stickers may result in covering stickers of some users, especially during the public event, where 156 respondents used one large map. Respondents were not limited by the number of points to locate on the map and they could also attach a comment to a point where needed. With the digital version, respondents also had the opportunity to mark their gender, and age, as well as whether they lived in Jeseník, where they lived in Jeseník and for how long they had lived in the city. Unfortunately these details were not collected during the analogue mapping due to time and technical constraints.

After negotiations with the city representatives, six questions were designed to analyse the citizens' perceptions about life in Jeseník. The author offered a list of questions previously used in other cities of the Czech Republic, where similar 


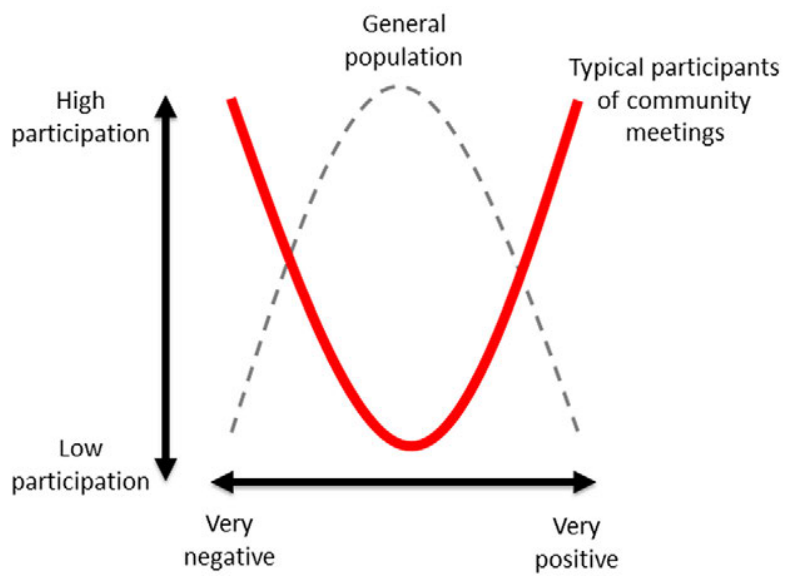

Fig. 2. An author's visualisation of the non-response bias in community affairs surveys.

research was realised. Based on this list, the city representatives selected following questions:

1. Where is a place with dangerous traffic?

2. Where is it dangerous?

3. Where do you miss something?

4. Where is it enjoyable?

5 . Where do you spend your free time?

6. Where is it deprived?

The questions represent the interests on the city and areas, where the public opinion is currently needed, therefore wide range of topics is covered by presented questions.

The total number of respondents was 533, which, because of the size of the sample, would be representative, with a $95 \%$ confidence level and a margin of error below 5\% (4.14\%). Nevertheless, the survey should not be considered as a representative sample as 1) the selection of participants was not random - only those interested in the topic took part, and 2) the demographic profile (age pyramid) does not have the normal distribution - citizens under 20 years old are over-represented in the sample. Regarding the first issue mentioned (1), the representation is also decreased by the participation bias (Lissner et al. 2003), sometimes called the non-response bias (Berg 2005), where participants with certain specifics (in this case a strong interest in specific topics) will take part in the survey (see Fig. 2) while citizens with no specific interest in public participation would not take the opportunity to fill in the map.

From the author's experience with similar participatory mapping activities, this uneven distribution of participants often appears at community meetings, nevertheless the results from online mapping tends to smooth out the differences among the extreme answers as wider spectrum of population usually participates in the online mapping. Nevertheless, the sample is sizeable enough to at least draw some conclusions and allow for suggestions for further improvement. As can be seen from the presented maps of the results (see Figs 4-9), the outcomes from the analogue map are often different to the results from the web-application, but when they are combined, the analogue map data do not significantly affect the final results.

The final data were presented in several visual forms. A webpage with a digital map was created so the general public can browse the data visualised as point clouds, heat maps and hexagon generalisations. Each topic can be visualised separately and answers can be filtered according to gender, whether the respondent lives in Jeseník and in which neighbourhood the respondent lives. Comments on the points, where applicable (in total 1,538 comments), are also available to read. Furthermore, the city council received the raw data as shapefiles, as well as six simple maps for immediate visualisation. The maps were created in open-source QGIS 2.18, with the utilisation of the heat-map visualisation method embedded in the software.

While the gender distribution of the respondents was quite balanced, with $46 \%$ males, $51 \%$ females and 3\% unstated, the age distribution (see Fig. 3) was more unbalanced, with a high over-representation of the population under 20 years old. One explanation is that the survey was heavily advertised among local young people at Jeseník's high school. The second explanation is

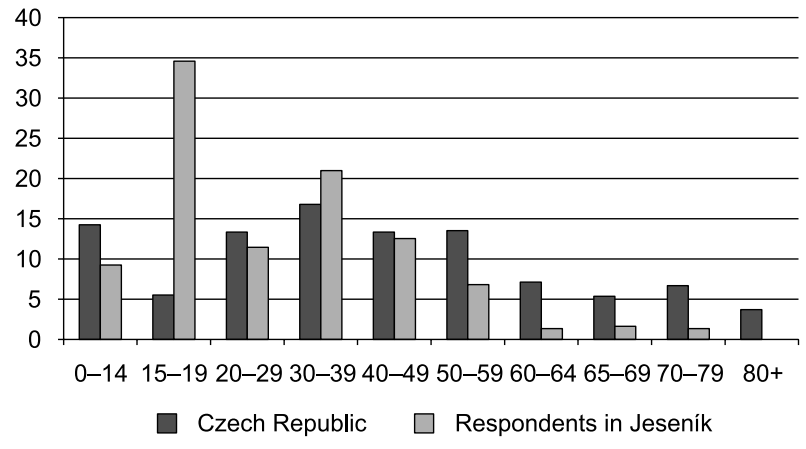

Fig. 3. Age distribution of overall population in the Czech Republic and age distribution of respondents in Jeseník. Data by Czech Statistical Office (2017). 
that young people are more active and interested in community affairs in Jeseník. The majority of the respondents $(75 \%)$ lived in Jeseník.

\section{Results}

In total, respondents marked 4,714 points in six questions (see Table 1). The majority $(94 \%)$ were collected via the web-map and in addition to these 4,452 points from the web map, 1,538 comments were attached to the locations. The most points were collected regarding the first question - "Where is it enjoyable?". There were, on average, 2.6 points per person, as opposed to an average of 1.4 points per person regarding the question "Where do you miss something?", which, in contrast, had the highest amount of comments.

On each map it is possible to differentiate between the responds (points) from the paper map and the web map. Nevertheless, as points from the paper map only made up $6 \%$ of the total responses, the final results are hardly affected by the more extreme responses on the paper map. The first map (Fig. 4) presents the initial, deliberately positive question related to the respondents' wellbeing in the city. On each map it is possible to see certain hot-spots; areas that were mentioned in significantly more responses than others. The responses to the question concerning the enjoyability of the city have highlighted four main hotspots - the main city square $(10 \%$ of all answers within the category), the Jeseník spa (located in the north-western corner of the map, $10 \%$ of answers), the local museum and the former monastery (both about 5\% of answers). Basically, these are the touristic attractions of the city and respondents also see them as places of beauty.

Some of the comments related to the above-mentioned locations were:

1. Main city square:

- Priessnitz's fountain is nicely done, loads of small jets. It looks great and it is source of fun for kids (female, 38),

- Nice square with good surface for prams - it bumbs just enough to get the kid to fall asleep (male, 40).

2. Jeseník spa:

- Nice view over whole Jeseník Mountains (female, 18),

- Thanks to nice views, coffee places and colonnade it is the most beautiful place in Jeseník (female, 17).

3. Local museum and former monastery:

- Nicely renovated place for kids as well as adults (female, 27),

- Well renovated areal, I appreciate it is open for public (female, 37).

The second question related to the perceived safety of the citizens (Fig. 5). Mapping perceptions of safety has been conducted in various contexts and countries, often as part of wider participatory mapping activities (Lawson et al. 2013, Salesses et al. 2013, Lipscomb 2014, Li et al. 2015, Melas et al. 2015, Traunmueller et al. 2015, Pánek et al. 2017a, Pánek et al. 2018). These researchers tend to describe the perception of safety as being linked with built-up areas, and that people's memories of a place last much longer than the real danger of criminality in various locations. In general, the locations that often appear in the results are those places with a high concentration of people (train stations, main squares), places with a lack of

Table 1. Basic statistics from the participatory mapping results.

\begin{tabular}{|c|c|c|c|c|c|c|c|}
\hline Parameter & $\begin{array}{l}\text { Where is it } \\
\text { enjoyable? }\end{array}$ & $\begin{array}{l}\text { Where is it } \\
\text { dangerous? }\end{array}$ & $\begin{array}{l}\text { Where is it } \\
\text { deprived? }\end{array}$ & $\begin{array}{l}\text { Where is a } \\
\text { place with dan- } \\
\text { gerous traffic? }\end{array}$ & $\begin{array}{l}\text { Where do you } \\
\text { miss something? }\end{array}$ & $\begin{array}{c}\text { Where do you } \\
\text { spend your free } \\
\text { time? }\end{array}$ & Total \\
\hline $\begin{array}{l}\text { Total number } \\
\text { of points }\end{array}$ & 1,063 & 784 & 733 & 688 & 576 & 870 & 4,714 \\
\hline $\begin{array}{l}\text { Points from } \\
\text { web map }\end{array}$ & 978 & 742 & 689 & 648 & 545 & 850 & 4,452 \\
\hline $\begin{array}{l}\text { Points from } \\
\text { paper map }\end{array}$ & 85 & 42 & 44 & 40 & 31 & 20 & 262 \\
\hline $\begin{array}{l}\text { Number of } \\
\text { comments }\end{array}$ & 308 & 275 & 244 & 233 & 310 & 168 & 1,538 \\
\hline
\end{tabular}


Where is it enjoyable?

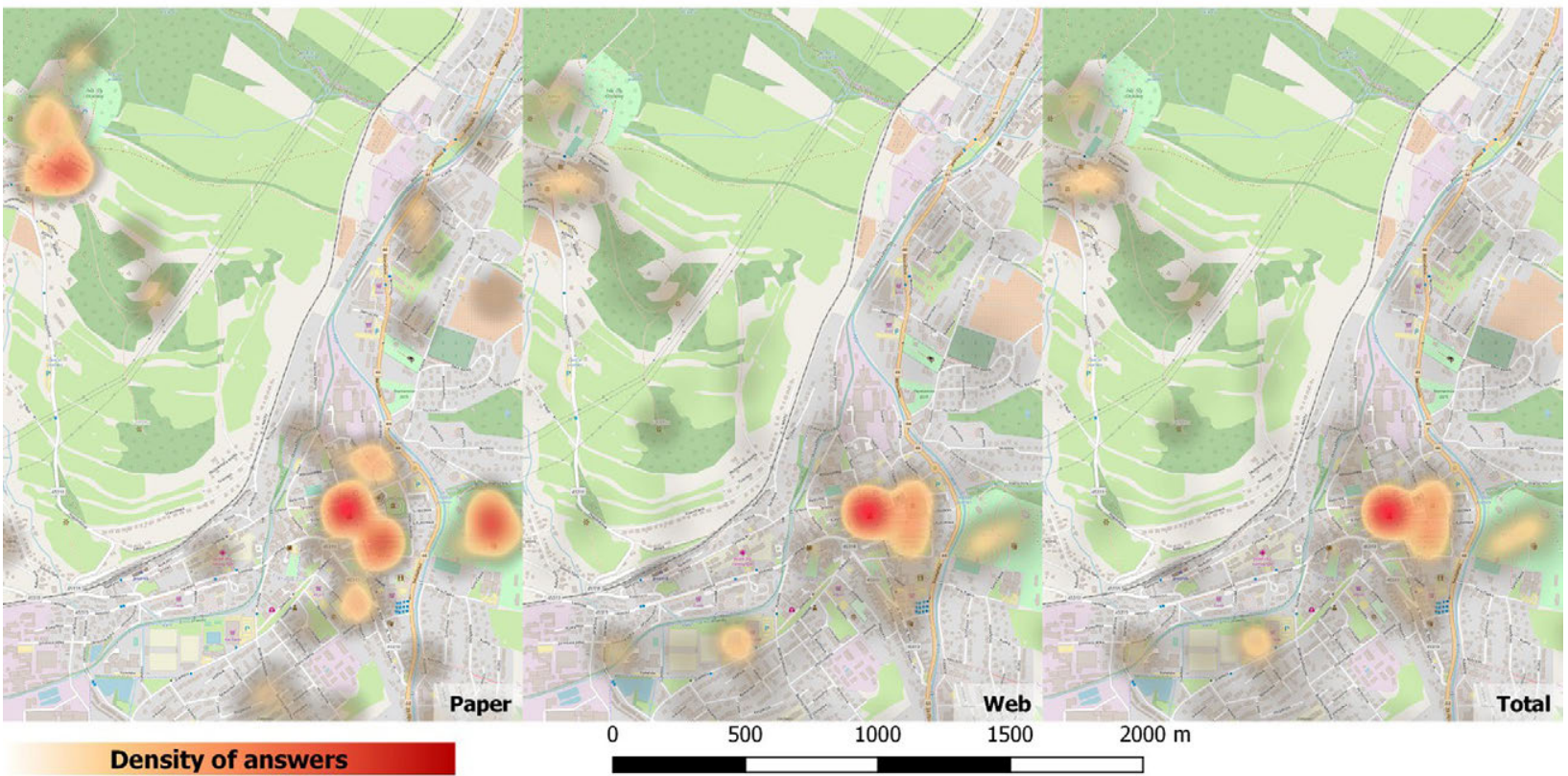

Fig. 4. Where do respondents think it is enjoyable in Jeseník?

visibility / day light (dark and narrow streets, park corners, underpasses) and excluded communities. People's perceptions of places vary depending on whether it is day or night, but they are usually perceived similarly by males and females. The four most common hot-spots mentioned in this question in Jeseník were similar to those found in research from other cities (Pánek et al. 2017a, Pánek et al. 2018). The most significant hot-spot, with $20 \%$ of all answers to this question, was the local bus station, followed by Smetana park (17\% of answers), Liberty park (6\% of answers) and the square of the heroes ( $4.5 \%$ of answers).

Some of the comments related to the above-mentioned locations were:

1. Bus station:

- Especially during the night, groups of youngsters or Gypsy (male, 21),

Where is it dangerous?

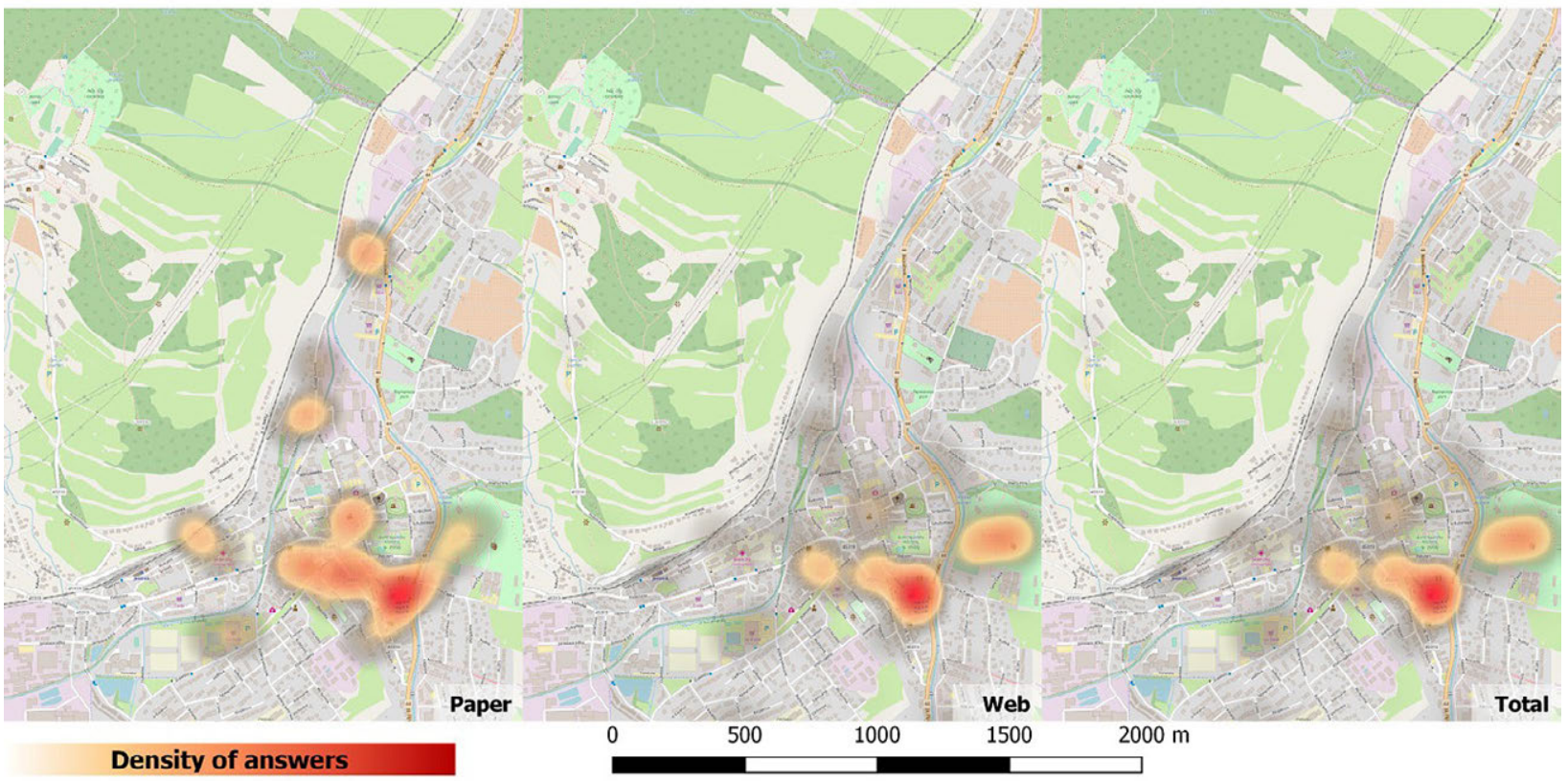

Fig. 5. Where do respondents think it is dangerous in Jeseník? 


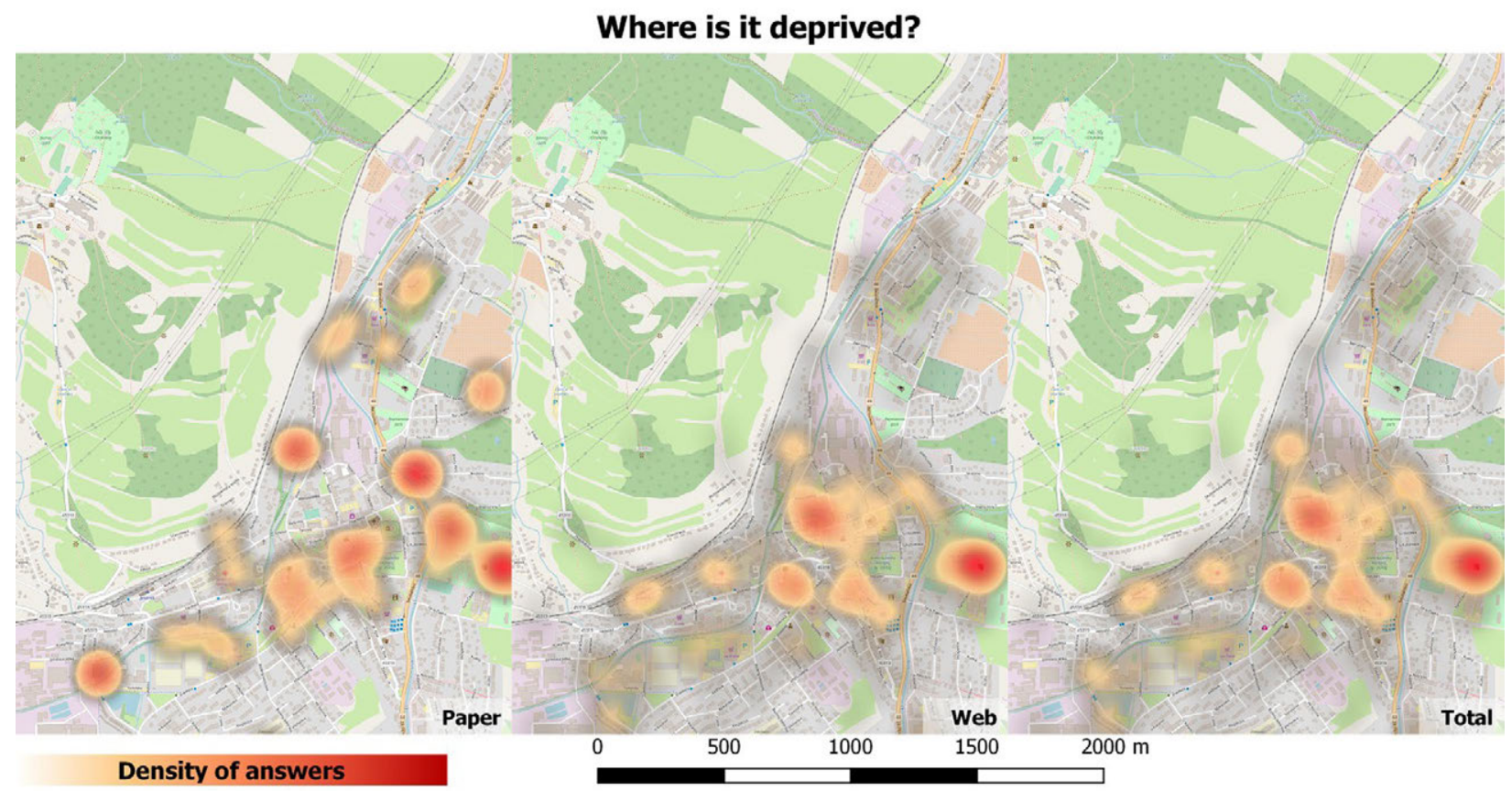

Fig. 6. Where do respondents think it is deprived in Jeseník?

- Around Penny Market, lots of homeless people (male, 43),

- Drug users (female, 14).

2. Smetana park:

- Quite dangerous place - drug addicts, drunks and homeless people (male, 21).

- The place is dirty and I wouldn't go there in the evenings (female, 27).

- Drunken teenagers, lack of police control (female, 66).

Mapping the general quality of the public environment, in this case study represented by question about deprived areas, is also common in perception research (Cinderby 1999, Pánek et al. 2017b). Although it seems that there are several hot-spots on the maps below (Fig. 6), only three are significant - the Vincent Priessnitz statue in Smetana park, which has already been mentioned above with $11 \%$ of all answers to the question. The next two hot-spots were the parking place at Tyrš street $(6 \%)$ and Heroes' Square $(3.5 \%)$. It is visible from the results that the perception of safety is sometimes linked with the perception of deprivation of the environment because Smetana Park and Heroes' Square appear in both categories. Similar results, linking perceived safety with a deprived environment and a need for change, have been observed in other cities in the Czech Republic, f.e. Brno (Pánek, Pászto 2017).
Some of the comments related to the above-mentioned locations were:

1. Vincent Priessnitz statue:

- Lost landmark of the Jeseník history (male, 36),

- It could be a nice place in summer for events, but all is in ruins (female, 18).

2. Tyrš street parking:

- Temporary and dusty parking lot - please make a proper paved surface here (male, 28),

- The city should decide, if this will be just another parking lot or small park with playground (male, 51).

While various parts of a city's infrastructure can be affected by traffic and can have an effect on people's perceptions of safety, the four top hot-spots in this case study, in relation to safety, were intersections (Fig. 7). The highest number of answers was for the intersection in the centre of the city (Dukelská Street and Liberty Square), with $14.5 \%$ of answers. The next three intersections each had $5 \%$ of the overall responses.

Some of the comments related to the above-mentioned locations were:

1. Dukelská and Liberty square:

- Missing traffic-lights (female, 43),

- The crossing is not planned well on such huge intersection. As a driver I can say it is dangerous place for both pedestrians as well as drivers (female, 18). 


\section{Where is a place with dangerous traffic?}

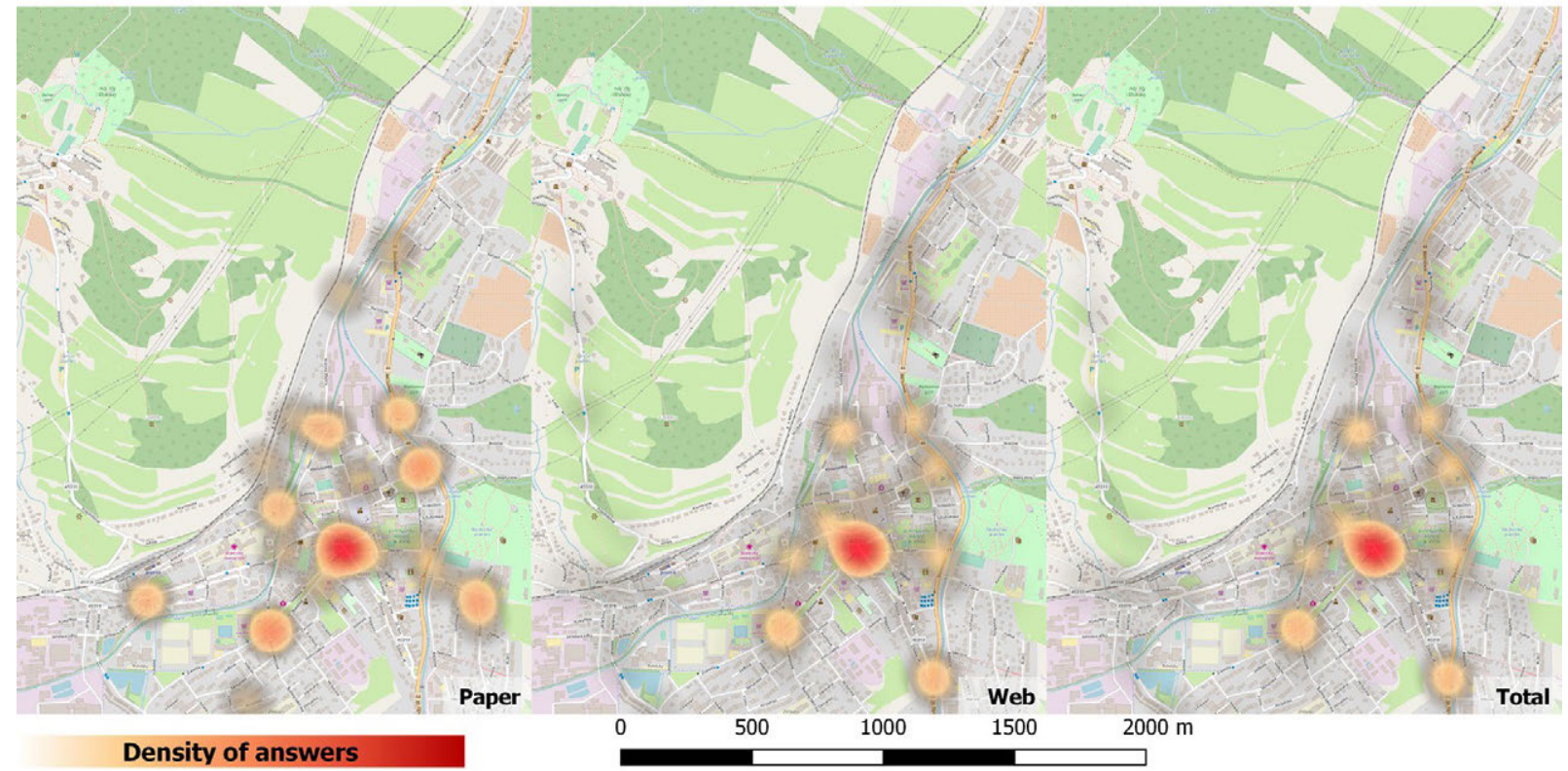

Fig. 7. Where do respondents think it is dangerous, traffic-wise, in Jeseník?

The question: Where do you miss something? provided an opportunity for respondents to suggest general improvements to public spaces in Jeseník (Fig. 8). Although the question was answered with the least number of points, it also attracted the most comments. In relation to location, the most marked places were the main city square $(12 \%)$, the sports hall $(5 \%)$ and the city market $(5 \%)$. When analysing the comments, the areas mentioned the most were children's playgrounds, walkways, parking spots and green areas.

Some of the comments related to the above-mentioned locations were:

1. Main city square:

- I miss more urbna greenery (female, 27),

- Little bit more shade (male, 68),

- Public toilet (female, 45),

- Free Wi-Fi (male, 28).

\section{Where do you miss something?}

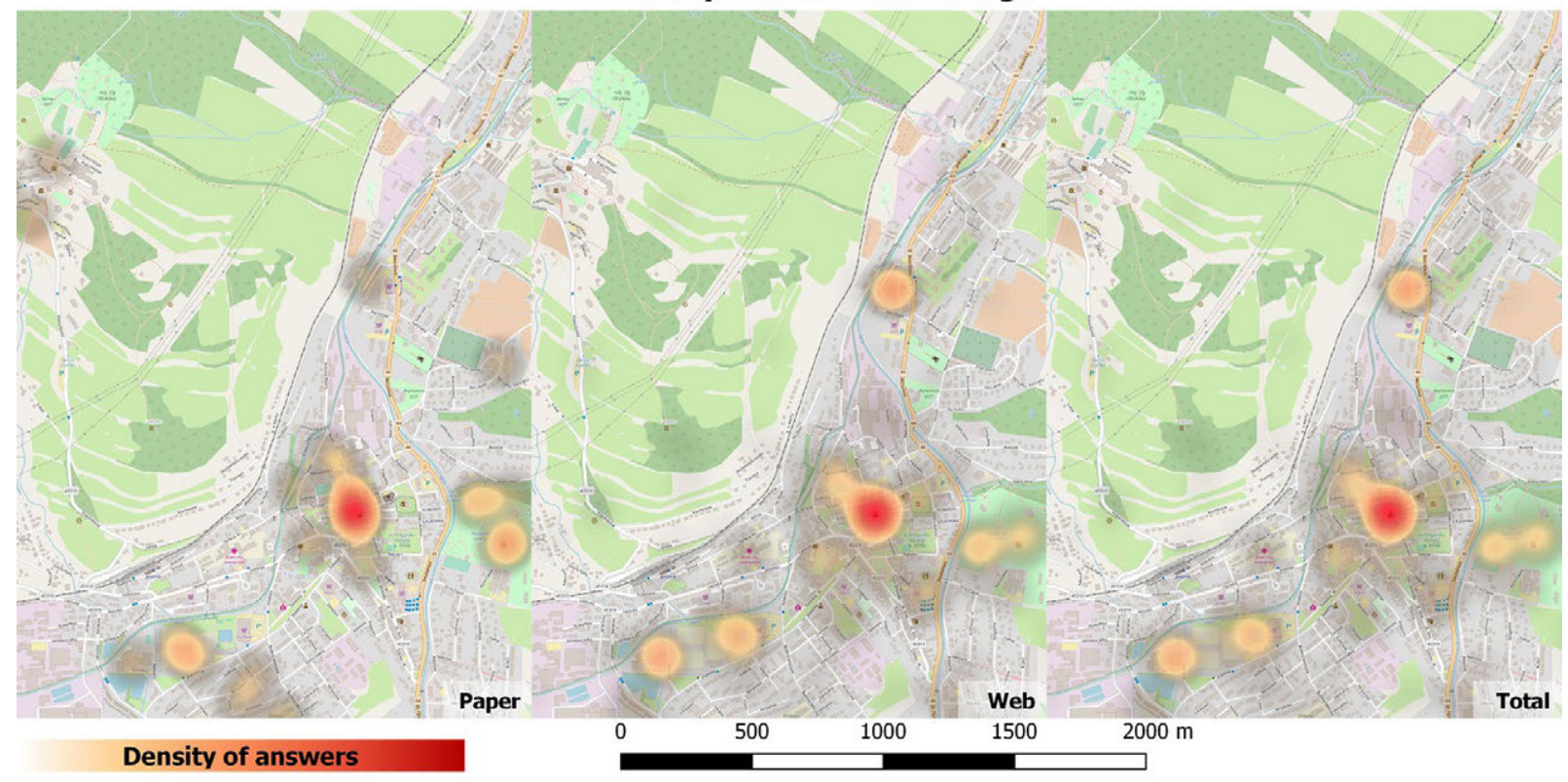

Fig. 8. Where do respondents miss something in Jeseník? 


\section{Where do you spend your free time?}

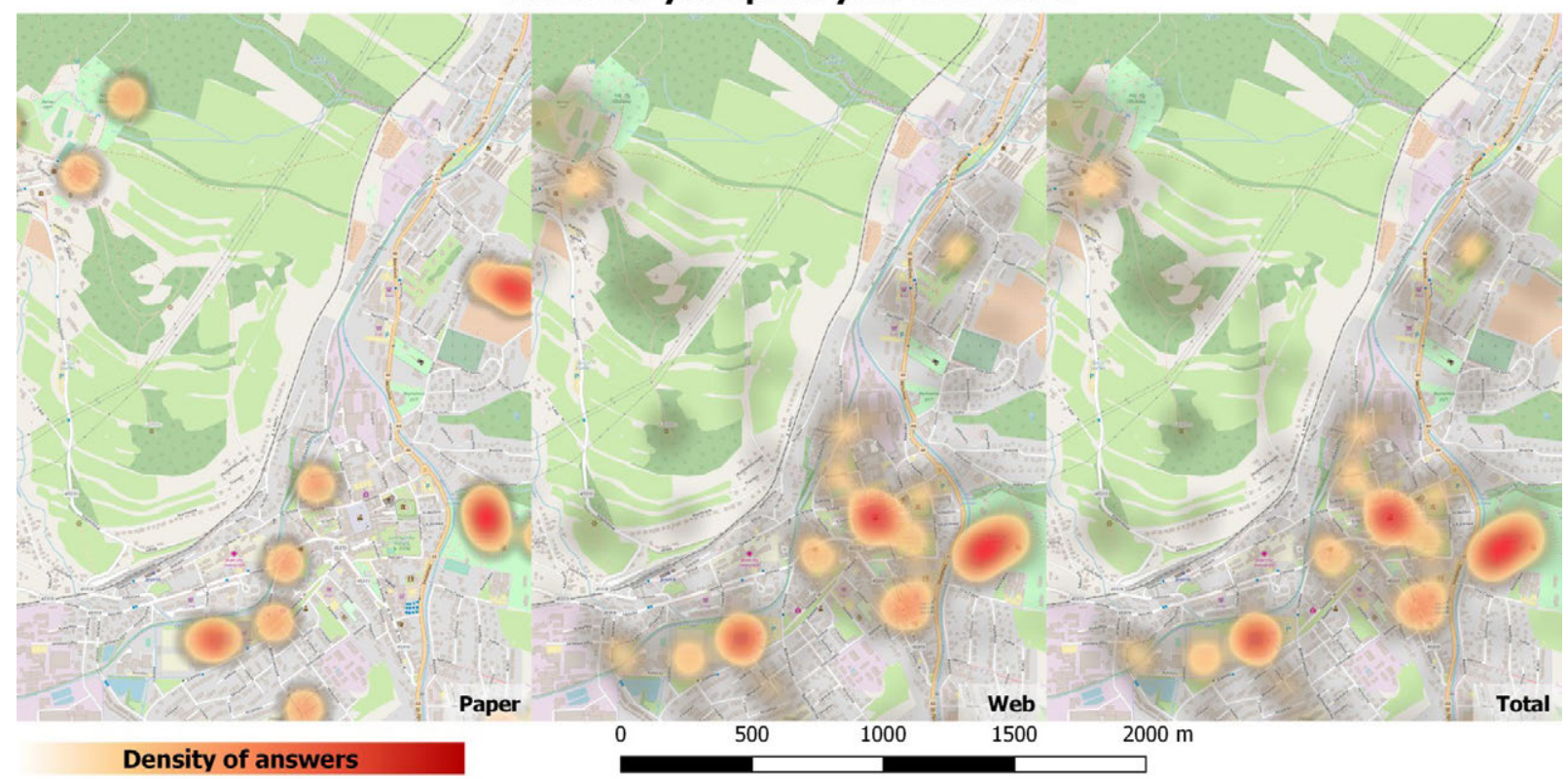

Fig. 9. Where do respondents spend their free time in Jeseník?

The last question was related to the free time preferences of Jeseník's residents (Fig. 9). Smetana park was considered to be the second most dangerous place in the city, but it is also the most popular location, where citizens of Jeseník spend their free time (9\% of answers). The next two locations were by the main square $(5 \%)$ and at the city pool (3.5\%).

Some of the comments related to the above-mentioned locations were:

1. Smetana park:

- We come here with friends to relax, to juggle and walk on slack-line (female, 27),

- The grass is not maintained, no new trees, springs are not working, the theatre is rusty - this all is deteriorating my experience from once favourite place (female, 35).

\section{Comparing the results based on the respondents demographics}

Where is it enjoyable? was the most answered question and it was used to demonstrate the main differences among the various demographic groups (Fig. 10). Beside the practical aim of the case study, which was to support the Jeseník municipality with participatory planning, the author was interested in finding which groups' answers showed the biggest differences. Would it be the age groups, gender groups or neighbourhood groups? The age group was divided into two subgroups - young people (under 20 years old) and citizens over 20 years old. The age groups were selected based on the massive campaign on Jeseník's high-school and the fact, that average age for leaving Czech high-school is 19. By this, the author filtered answers from high-school respondents from the rest of the population. The neighbourhood group was also divided into two subgroups - citizens from the location Pod Chlumem $(n=128)$ and citizens from other parts of Jeseník. The neighbourhood Pod Chlumem was selected as one third of the sample $(35 \%)$ came from this area, and the other neighbourhoods had lower results. As can be identified from the visualisation below, there are almost no differences in the answers of males and females as well as residents from area Pod Chlumem in comparison to answers from the rest of the dataset. The visible difference is among selected age groups. The amount of points does not play any role, as the hotspots/density are generated for each question separately. Young people have a wider range of views about the enjoyable places in Jeseník than the rest of the population. While the respondents aged over 20 mainly agreed on hotspots around the main city square, the young people included more locations with a wider range of uses - the swimming pool, the shopping mall, various parks as well as sports grounds. 


\section{Where is it enjoyable?}

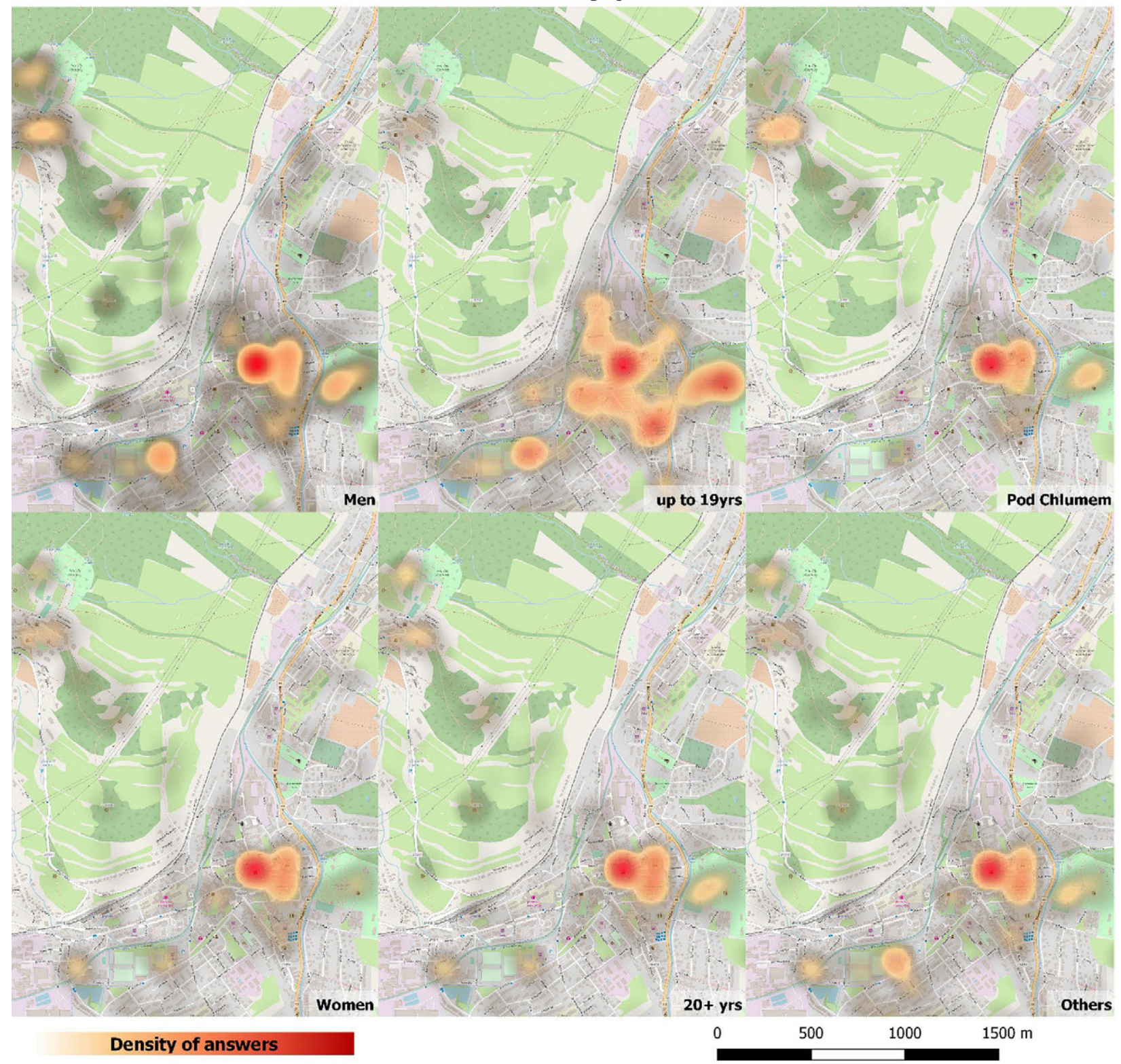

Fig. 10. Differences among selected groups' answers to the question Where is it enjoyable in Jeseník?

\section{Usability of the results}

In order to evaluate the usability of the results from the participatory perception mapping, the author asked the representative of the municipality to share how they would use the results and what they would change about the process of mapping people's perceptions in future deployments. The Vice-Mayor explained that the results were divided based on the topics. The results regarding general safety and traffic safety were given to the national police and the city police. Employees of the city's technical services were interested in the deprived areas of the city and planned to increase the frequency of mowing and cleaning in the parks. The city police also announced an increase in patrols through city parks seen to be dangerous spots and increased surveillance at pedestrian crossings on main roads. It was also discovered, based on the citizens' reports, that a local supermarket had built an intersection for cars leaving their parking lot in conflict with zoning regulations. The main reason people consider this intersection to be dangerous is the lack of visibility caused by an illegally placed billboard. 
Furthermore, in 2018 a new strategic plan and action plan for the city will be issued. The results of the mapping exercise will be part out of the inputs for both plans. In relation to concerns about what can be improved in the methodology, the municipality representative suggested the survey could be more location specific - create emotional maps for specific areas of the city in order to achieve more finely-tuned results.

\section{Conclusions}

The participatory mapping exercise in Jeseník provided not only valuable data and insights for the local municipal representatives, but also an opportunity for the citizens of Jeseník to actively participate in the local decision-making process. From an academic point of view, interesting results were observed as different age groups answered with contrasting opinions for the same questions. It was observed that gender or home location within the city did not influence the results, but the age of the respondents did. Significant differences between the answers of young people and the population over 20 years old were observed. If this is a general trend, it still needs to be investigated, but the preliminary results from this case study look promising.

\section{Acknowledgement}

This work was supported by the Czech Science Foundation within a project titled Democratic Innovations at the Local Level - Case study of the Czech Republic, Poland and Slovakia (No. 1720569S) and by the project Spatial Exploration of Economic Data: Methods of Interdisciplinary Analytics (Spationomy) funded by the European Union within the Erasmus+ programme (No. 2016-1-CZ01-KA203-024040).

\section{References}

Berg N., 2005. Non-Response Bias. In K. Kempf-Leonard, ed. Encyclopedia of Social Measurement. London: Academic Press: 865-873. Online: papers.ssrn.com/sol3/papers. cfm?abstract_id=1691967 (accessed September 25, 2017).

Brown G., Pullar D.V., 2012. An evaluation of the use of points versus polygons in public participation geographic information systems using quasi-experimental design and Monte Carlo simulation. International Journal of Geographical Information Science 26(2): 231-246.

Brydon-Miller M., Greenwood D., Maguire P., 2003. Why Action Research? Action Research 1(1): 9-28.

Cartwright W., 2012. Neocartography: Opportunities, issues and prospects. South African Journal of Geomatics 1(1): 14-31.

Cinderby S., 1999. Geographic information systems (GIS) for participation: the future of environmental GIS? International Journal of Environment and Pollution 11(3): 304-315.

Czech Statistical Office, 2013. Census 2011. Online: https:// www.czso.cz/csu/sldb/home (accessed August 3, 2018).

Czech Statistical Office, 2017. Demographic trends. Online: https://vdb.czso.cz/vdbvo2/faces/en/index. jsf? page $=$ profil - uzemi\&uzemiprofil $=31548 \& u=$ VUZEMI_97_19\# (accessed September 22, 2017).

Dunn C.E., 2007. Participatory GIS a people's GIS? Progress in Human Geography 31(5): 616-637.

Huck J., Whyatt D., Coulton P., 2014. Spraycan: A PPGIS for capturing imprecise notions of place. Applied Geography 55: 229-237.

Jankowski P., Czepkiewicz M., Młodkowski M., Zwoliński Zb., 2016. Geo-questionnaire: A Method and Tool for Public Preference Elicitation in Land Use Planning. Transactions in GIS 20(6): 903-924.

Lawson A.R., Pakrashi V., Ghosh B., Szeto W.Y., 2013. Perception of safety of cyclists in Dublin City. Accident; analysis and prevention 50, pp. 499-511.

Li X., Zhang C., Li W., 2015. Does the Visibility of Greenery Increase Perceived Safety in Urban Areas? Evidence from the Place Pulse 1.0 Dataset. ISPRS International Journal of Geo-Information 4(3): 1166-1183.

Lipscomb S., 2014. Visualizing Perceived Safety in a Campus Environment. Online: http://www.imagin.org/awards/ sppc/2014/papers/sam_lipscomb.pdf (accessed December 1, 2015).

Lissner L., Skoog I., Andersson K., Beckman N., Sundh V., Waern M., Zylberstein D.E., Bengtsson C., Björkelund C., 2003. Participation bias in longitudinal studies: experience from the population study of women in Gothenburg, Sweden. Scandinavian Journal of Primary Health Care 21(4): 242-247.

Melas P., Correndo G., Middleton L., Sabeur Z.A., 2015. Advanced Data Analytics and Visualisation for the Management of Human Perception of Safety and Security in Urban Spaces. In: R. Denzer, R.M. Argent, G. Schimak, J. Hřebíček (eds.), Environmental Software Systems. Infrastructures, Services and Applications. ISESS 2015. IFIP Advances in Information and Communication Technology, Springer, Cham, v. 448: 445-454.

Pánek J., 2016. From Mental Maps to GeoParticipation. The Cartographic Journal 53(4): 300-307. DOI: 10.1080 /00087041.2016.1243862.

Pánek J., Mařincová L., Putalová L., Hájek J., Marek L., 2017b. Crowdsourcing of environmental health quality perceptions: A pilot study of Kroměříž, Czech Republic. In: M. Leitner, J.J. Arsanjani (eds.), Citizen Empowered Mapping. Geotechnologies and the Environment, Springer, Cham, v. 18: 261-280.

Pánek J., Pászto V., 2017. Crowdsourcing mapping and participatory planning support system: Case study of Brno, Czechia. In: M. Paterson (ed.), In: Peterson M. (eds.) Advances in Cartography and GIScience. ICACI 2017. Lecture Notes in Geoinformation and Cartography. Springer, Cham: 61-73. 
Pánek J., Pászto V., Marek L., 2017a. Mapping emotions: spatial distribution of safety perception in the city of Olomouc. In: I. Ivan, A. Singleton, J. Horák, T. Inspektor (eds.), The Rise of Big Spatial Data. Lecture Notes in Geoinformation and Cartography. Springer, Cham: 211-224.

Pánek J., Pászto V., Šimáček P., 2018. Spatial and Temporal Comparison of Safety Perception in Urban Spaces. Case Study of Olomouc, Opava and Jihlava. In: I. Ivan, J. Horák, T. Inspektor (eds.), Dynamics in GIscience. GIS Ostrava 2017. Lecture Notes in Geoinformation and Cartography. Springer, Cham: 333-346. DOI: 10.1007/978-3319-61297-3_24.

Patryn L., 1912. Der Ergebnisse der Volkszählung vom 31. Dezember 1910 in Schlesien. Online: www.sbc.org.pl/dli- bra/publication/edition/11734?id=11734 (accessed September 22, 2017).

Rød J.K., Ormeling F., Van Elzakker C., 2001. An agenda for democratising cartographic visualisation. Norsk Geografisk Tidsskrift 55(1): 38-41.

Salesses P., Schechtner K., Hidalgo C.A., 2013. The Collaborative Image of the City: Mapping the Inequality of Urban Perception. PLOS ONE 8(7): e68400.

Traunmueller M., Marshall P., Capra L., 2015. Crowdsourcing Safety Perceptions of People: Opportunities and Limitations. In: T.Y. Liu, C. Scollon, W. Zhu (eds.), Social Informatics. SocInfo 2015. Lecture Notes in Computer Science, Springer, Cham, v.9471: 120-135. 